\title{
Pure Intraventricular Origin of Gliosarcoma - A Rare Entity
}

\section{Saf Intraventriküler Kökenli Gliosarkom - Nadir Bir Durum}

\author{
Hrishikesh SARKAR, Sunil K, Siddhartha GHOSH \\ Apollo Speciality Hospital, Department of Neurosurgery, Chennai, India
}

Corresponding Author: Hrishikesh SARKAR / E-mail: hrishikesh.sarkar@hotmail.com

\begin{abstract}
Gliosarcomas (GS) are high grade, rare tumours. Radiologically they are seen as a surfacing lesion, often having a thick dural attachment located within the parenchyma of the brain. We report a very unusual case of an intraventricular non-parenchyhmal gliosarcoma in a 60-yearold female. Magnetic resonance imaging of the brain revealed a well defined brilliantly enhancing mass located in the septal region and extending into the body and the frontal horn of the lateral ventricle on either side. The mass was isointense on T1-weighted sequences and hypointense on T2-weighted sequences. Very few reports that describe this entity exist and our case report adds to the sparse literature.
\end{abstract}

KEYWORDS: Gliosarcoma, Intraventricular, Non parenchymal

öz

Gliosarkomlar (GS) yüksek dereceli, nadir tümörlerdir. Radyolojik olarak sıklıkla beyin parankiminde bulunan kalın dural bir tutulma kısmıyla yüzeye çıkan bir lezyon olarak görülürler. Burada 60 yaşında bir kadında intraventriküler nonparenkimal gliosarkom şeklinde çok nadir bir vakayı sunuyoruz. Beynin manyetik rezonans görüntülemesi septal bölgede çok parlak şekilde kontrast madde tutan iyi tanımlanmış bir kitleyi ve her iki tarafta lateral ventrikülün frontal kornusu ve gövdesine uzanmasını gösterdi. Kitle T1 ağırlıklı dizilerde izointens ve T2-ağırlıklı dizilerde hipointensti. Bu varlığı tanımlayan çok az sayıda rapor vardır ve vaka raporumuz bu az sayıda yayına katkıda bulunmaktadır.

ANAHTAR SÖZCÜKLER: Gliosarkom, İntraventriküler, Nonparenkimal

\section{INTRODUCTION}

Gliosarcomas (GS) are extremely high grade, rare and bimorphous tumours, predominantly lobar in location (9). On imaging, they are seen as surfacing lesion, often having a thick dural attachment (5). We report a very unusual case of an intraventricular gliosarcoma (IVGS) in a 60-year-old female. Till date, only a few reports of this pathological entity have been published $(2,4,6,8)$.

\section{CASE REPORT}

A 60-year-old female presented with one and half-month history of recurrent headache and vomiting suggestive of raised intracranial pressure. There was history of social disinhibition for three weeks. On examination she had reduced attention span and there were frontal lobe release signs. Fundi showed papilledema. Magnetic resonance imaging of the brain revealed a well defined brilliantly enhancing mass located in the septal region and extending into the body and the frontal horn of the lateral ventricle on either side (Figure $1 A, B)$. The mass was isointense on T1-weighted sequences and hypointense on T2-weighted sequences. Diffusion weighted imaging and apparent diffusion coefficient mass showed restricted diffusion in the major portion of the tumor consistent with high degree of cellularity except in its central part where it seemed necrotic (Figure 1C,D).
Due to the resultant mass effect there was obstructive hydrocephalus. Possibilities of a high-grade ependymoma and high-grade glioma were considered. She underwent neuronavigation guided right-sided transfrontocortical, transventricular approach and gross total excision of the mass. Intraoperatively, a well-defined grayish white, firm, fibrous and highly vascular mass infiltrating the septum pellucidum was visualized. The mass was extending into both the lateral ventricles. As anticipated, the core of the tumor was necrotic. The ependymal walls were free of the tumor suggesting pure septal origin of this lesion. There was no evidence of any bleed or calcification. Based on the radiological and intra operative features, possibilities of a high-grade septal glioma, central neurocytoma or an ependymoma was considered. Histhopathological examination showed bimorphic pattern consisting of a glial and sarcomatous component (Figure 2A). There were features of mitoses, microvascular proliferation and zones of necrosis (Figure 2B). The sarcomatous areas were rich in vimentin and immmunonegative for glial fibrillary acidic protein (GFAP) (Figure 2C). The glial zone was deprived of vimentin and positive for GFAP. The sarcomatous component was also negative for smooth muscle actin (Figure 2D). Histopathological features were suggestive of gliosarcoma. Postoperatively the patient made a good recovery and was advised chemoradiation therapy. 


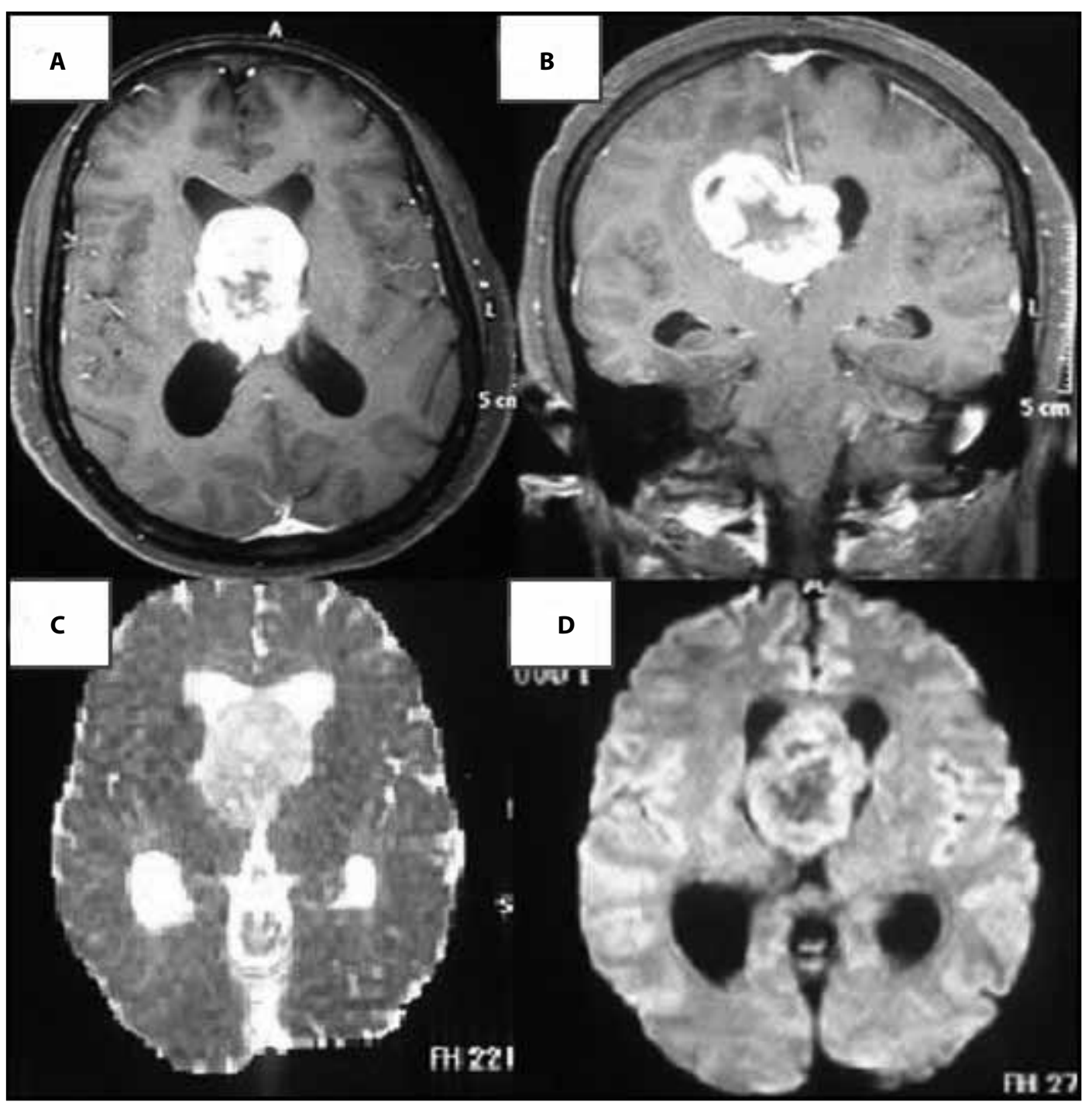

Figure 1: MRI of brain with axial (A) and coronal (B) sections, contrast injection, showing enhancing mass located in the septal region and extending into the body and the frontal horn of the lateral ventricle on either side. Diffusion weighted imaging and apparent diffusion ( $C$ and D) coefficient mass showed restricted diffusion in the major portion of the tumor consistent with high degree of cellularity except in its central part where it seemed necrotic.

\section{DISCUSSION}

Common intraventricular gliomas are ependymomas, subependymoma and high-grade astrocytomas. IVGS are extremely rare $(3,7,10)$. Pure IVGS have been described sparsely in the literature $(6,2,4,8)$. Higashino et al reported 29-year-old male with a lateral ventricular gliosarcoma (6). The authors believed that this GS arose from a transformed ependymoma, as an initial stereotactic biopsy showed the tumor to be an ependymoma. Moiyadi et al also reported IVGS located within the temporal horn and atrium of the lateral ventricle (8). There were no ependymal areas on histology. The authors concluded it to have originated from a subependymal location that appeared to protrude into the ventricular system.

Our case was similar to that described by Govindan et al (4). The lesion appeared to have arisen from the septal wall and then protruded into both the lateral ventricles and blocked them. This is the second such case of an exclusive IVGS. It is again possible that the lesion could have arisen from an ependymal origin. However, there was no histopathological evidence of any ependymal component. There is also a suggestion that the bimorphic nature of this tumor could be a result of poorly understood epigenetic phenomena (8).

The overall clinical and prognostic features of gliosarcomas are similar to glioblastomas. Overall median survival has been reported to be 6-14 months (3). Spread of gliosarcoma via blood and cerebrospinal fluid has been shown (1). Therefore location within the ventricle has a greater potential for transependymal spread, and as suggested by Moeyadi et al, complete neuraxial screening may be necessary to look for distant spread (8).

In conclusion, gliosarcomas, though rare, can be located exclusively within the ventricular system as seen in our case. Neuraxial screening may be required for further follow up. 


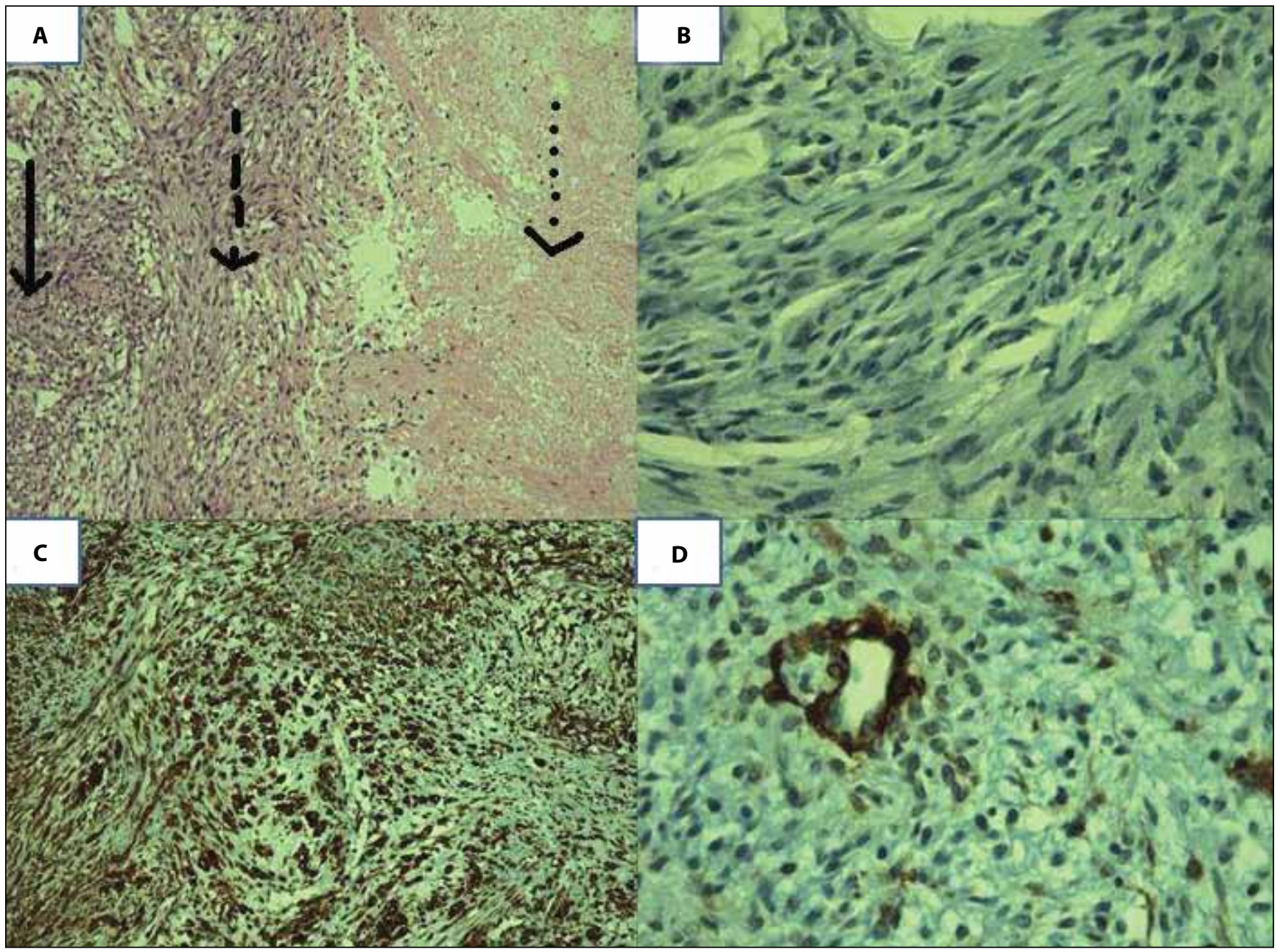

Figure 2: Histhopathological examination showed (A) bimorphic pattern consisting of a glial (straight arrow) and sarcomatous component (dashed arrow). Zone of necrosis is seen in (a) and marked as dotted arrow. (B) Mitoses and microvascular proliferation. (C) The glial zone was deprived of vimentin and positive for GFAP. (D) The sarcomatous component was also negative for smooth muscle actin.

\section{REFERENCES}

1. Beaumont TL, Kupsky WJ, Barger GR, Sloan AE: Gliosarcoma with multiple extracranial metastases: Case report and review of the literature. J Neurooncol 83:39-46, 2007

2. Behling $E$, Birbe $R$, Veznadaroglu $E$, Andrews DW, Flanders A, Kenyon LC: Gliosarcoma arising from an anaplastic ependymoma: A case report of a rare entity. Hum Pathol 35:512-516, 2004

3. Galanis E, Buckner JC, Dinapoli RP, Scheithauer BW, Jenkins $\mathrm{RB}$, Wang $\mathrm{CH}$ : Clinical outcome of gliosarcoma compared with glioblastoma multiforme: North central cancer treatment group results. J Neurosurg 89:425-430, 1998

4. Govindan A, Bhat DI, Mahadevan A, Chakraborti S, Sampath S, Chandramouli BA, Shankar SK: An unusual case of intraventricular gliosarcoma. Clin Neuropathol 28: 379-383, 2009
5. Han L, Zhang X, Qiu S, Li X, Xiong W, Zhang Y, et al: Magnetic resonance imaging of primary cerebral gliosarcoma: A report of 15 cases. Acta Radiol 49:1058-1067, 2008

6. Higashino T, Inamura T, Kawashima M, Ikezaki K, Miyazono M, Yoshiura T et al: A lateral ventricular gliosarcoma arising in an ependymoma. Clin Neuropathol 20:219-223,2001

7. Kleihues $\mathrm{P}$, Burger PC, Scheithauer BW: The new WHO classification of brain tumors. Brain Pathol 3:255-268,1999

8. Moiyadi A, Sridhar E, Jalali R: Intraventricular gliosarcoma: Unusual location of an uncommon tumor. J Neurooncol 96:291-294, 2010

9. Morantz RA, Feigin I, Ransohoff JIII: Clinical and pathological study of 24 cases of gliosarcoma. J Neurosurg 45:398-408, 1976

10. Waldron JS, Tihan T: Epidemiology and pathology of intraventricular tumors. Neurosurg Clin N Am 14:469-482, 2003 